UDK 342.7: 616-036.22

Review article

\title{
THE IMPACT OF COVID-19 ON CHILDREN'S RIGHTS*
}

\author{
Sandra Winkler, PhD, Assistant Professor \\ Faculty of Law in Rijeka \\ Hahlić 6, 51000 Rijeka, Croatia \\ swinkler@pravri.hr
}

\begin{abstract}
In emergency situations, the people most affected are often those who are already vulnerable, and this certainly includes children. The "new normal" we are living in to defend ourselves against this tiny yet dangerous enemy has serious repercussions on children's lives. This becomes even more evident if we think of those children who are doubly vulnerable - they are even more fragile because they live in conditions of particular hardship when they live outside their family, have a disability, or live in poverty.

Since the beginning of the Covid-19 pandemic, we have witnessed the proliferation of numerous initiatives by various national and international children's rights institutions, which have called for urgent measures to protect children's rights. At this precise moment, the concept of the child's best interests is also reinterpreted as a result of a reasonable compression of certain children's rights and the prevalence of others.

The present paper will attempt an analytical reconstruction of children's fundamental rights by analyzing how these rights have changed during the pandemic. In fact, it is necessary to know if andlor how much have the rights of minors changed as a result of the emergency.

The second part of the paper is dedicated to the question of which children's rights will be most compromised or changed in the post-Covid-19 era. In reflecting on the inevitable consequences that the pandemic will leave on the delicate balance of the development of children's rights, the author will offer some proposals on how to contain the encountered difficulties.
\end{abstract}

Keywords: children's Rights, child's best interest, Covid-19, pandemic, right to family life.

\section{INTRODUCTORY REMARKS}

The pandemic caused by the Covid-19 outbreak is putting the whole of society and, above all, the protection of the fundamental rights guaranteed to each indi-

This work has been fully supported by the University of Rijeka under the project uniri-drustv-18-252 "Legal aspects of the digital transformation of society". 
vidual, to the test. ${ }^{1}$ The "new normal" that has become our collective reality has inevitably lead to questions about how and to what extent has the pandemic affected people's lives, their personal relationships, as well as how these will change once the acute phase of this health emergency is finally over. ${ }^{2}$

It is widely known that, in emergency situations, the most affected groups are often those who are already vulnerable, and this certainly includes children.

As to the impact of Covid-19 on children's rights, in the months dominated by the health emergency, numerous initiatives have been undertaken by national ombudspersons for children, ${ }^{3}$ by the European Network of Ombudspersons for Children (ENOC), ${ }^{4}$ as well as by $\mathrm{UNICEF}^{5}$ aimed at calling for urgent measures to protect the rights of minors, paying particular attention to those who are even more defenseless because they live in conditions of particular hardship on account of living outside their family, due to disability, or poverty. ${ }^{6}$

The purpose of this paper is to reflect on how the pandemic is impacting children's lives and rights. Precisely, it is manifest that the impact is strong. The health emergency we are living in, in some respects, is reshaping many dynamics. Thus, it is necessary to think about the consequences this pandemic will leave on minors, especially in the post-Covid period. In other words, one has to question whether this impact, which now, in the midst of the pandemic, is resulting in a clear weakening

1 For an overview of how Covid-19 disrupted the world and rights, among many, see Pistor, K., Law in the Time of COVID-19, 2020. Books. 240. Available at: [https://scholarship.law.columbia.edu/ books/240]. Accessed 1 March 2021. Dolso, G. P.; Ferrara, M. D.; Rossi, D. (eds.), Virus in fabula, Diritti e Istituzioni ai tempi del covid-19, EUT Edizioni Università di Trieste, 2020. Available at: [https://www.openstarts.units.it/handle/10077/30878] Accessed 1. March 2021. In particular, as to the Human Rights see Gioffredi, G., La pandemia Covid-19 e la tutela dei diritti umani nel sistema delle Nazioni Unite, in Ellerani, P.; Cristante, S. (eds.), Le Scienze Umane alla prova della distanza sociale, Liber-O. Collana Didattica Open Access dell'Università del Salento, 2020, p. 61-74.

2 For a very interesting analysis from a comparative perspective see Cuocolo, L. (eds), I diritti costituzionali di fronte all'emergenza Covid-19. Una prospettiva comparata, Osservatorio emergenza covid-19 18.3.2020., Federalismi.it, pp. 3-96. Referring to an interesting analysis of pandemics in ancient history see Fiorentini, M., Caelum pestilens. Riflessi delle pandemie antiche nel diritto romano, in Dolso, G. P.; Ferrara, M. D.; Rossi, D. (eds.), Virus in fabula, cit., pp. 47-60.

3 About the Croatian Ombudsperson for Children see: [http://dijete.hr/category/koronavirus/], Accessed 23 March 2021.

4 European Network of Ombudspersons for Children (ENOC) see [http://enoc.eu/?p=3515], Accessed 23 March 2021. In particular see the Report on Ombudspersons and Commissioners for Children's Challenges and Responses to COVID-19.

5 For all Covid-19 news and resources, as well as tips on how to protect children and families, see [https://www.unicef.org/coronavirus/covid-19], Accessed 23 March 2021.

6 Many interesting documents written by the Committee on the Rights of the Child can be found here: [https://www.ohchr.org/EN/HRBodies/CRC/Pages/CRCIntro.aspx], Accessed 23 March 2021. 
of children's rights, making them even more vulnerable, could be an opportunity to further strengthen the legal position of children or, at least, to make it clear to those who should be protecting children's rights how many weaknesses have emerged - even more clearly - in this serious world crisis. Indeed, as it will be pointed out in this paper, while it is beneficial to have an exhaustive catalogue of children's rights, there is still a long way to go before children can fully enjoy their rights and have their "voice" heard.

At this very moment, it should be noted that many personal freedoms are being restricted, compressed by putting the protection of the right to health (individual and collective) first. The question now is whether these current restrictions should be considered ordinary or extraordinary. In some cases, the question is whether this limitation is proportional to the emergency. ${ }^{7}$ However, once the emergency is over, it will be necessary to talk about life not during the coronavirus, but after it, which will require many measures everywhere.

This paper will, therefore, attempt to reconstruct, at the supranational level, the fundamental rights to which every child is entitled. After identifying these rights and attempting to interpret the complex concept of the best interests of the child, the impact of the Covid-19 pandemic on children's rights will be examined.

\section{OVERVIEW OF THE FUNDAMENTAL RIGHTS OF CHILDREN}

Before analyzing what changes are taking place as a result of the Covid-19 pandemic, it is necessary to provide an overview of the fundamental rights of children. ${ }^{8}$ It should also be pointed out that all reconstructions and reflections start from international and supranational sources, in particular, European sources (here, we refer to the term "European" in a broader sense than EU law). ${ }^{9}$ The analysis will be limited to shared supranational principles and values, given the common framework of fundamental principles guaranteed to the individual children, in this specific case - on a supranational level, which can be transposed to the realities of the different European legal systems. ${ }^{10}$

Dolso, G. P., Emergenza sanitaria e libertà di circolazione, in Dolso, G. P.; Ferrara, M. D.; Rossi, D. (eds.), Virus in fabula, cit., pp. 263-278.

8 For more see Hrabar, D. (ed.), Prava djece. Multidisciplinarni pristup, Pravni fakultet Sveučilišta u Zagrebu, Zagreb, 2016; Rešetar, B. (ed.), Dijete i pravo, Pravni fakultet u Osijeku, Osijek, 2009.

9 Majstorović, I., Europski obiteljskopravni sustav zaštite djece, in Hrabar, D. (ed.), Prava djece. Multidisciplinarni pristup, Pravni fakultet Sveučilišta u Zagrebu, Zagreb, 2016, pp. 39-62.

10 Referring to the Croatian legal system see ex plurimis Hrabar, D., Dijete - Pravni subjekt u obitelji, Zagreb, 1994. 
First and foremost, reference should be made to an international source that is the most important one in terms of protecting the fundamental rights of children. Indeed, the UN Convention on the Rights of the Child signed in New York in 1989 represents a radical change in the view of children's rights. This convention, certainly one of the most important documents in the history of the United Nations and one of the most ratified ones of all time, imposes a paradigm shift. ${ }^{11} \mathrm{By}$ laying down a catalogue of fundamental rights of minors with regard to both their relations in their own families, as well as in the community as a whole, the UN Convention on Children's Rights leads individual legislators, as well as international bodies and the European Union itself, to a clear reinterpretation of fundamental rights within the family in a way centered on children. ${ }^{12} \mathrm{~A}$ first reading of the text of the Convention is enough to see that among the most important rights of every child are: 1 ) the child's right to life and health; 2 ) the right of the child to live with his or her parents; 3) the right to education; 4) the right to be informed and freely express one's opinion; 5) the right to know one's origins; 6) the right to psychophysical and emotional development, and 7) the right to play.

These rights are also protected at the European level, albeit partly through the role played by the UN Convention. ${ }^{13}$ Namely, the UN Convention on children's rights is the foundation for the regulation of children's rights in many legal systems and, obviously, also in the European Union. ${ }^{14}$ In this regard, reference should be made to Article 24 of the Charter of Fundamental Rights of the EU, which states in its first paragraph that "children shall have the right to such protection and care as is necessary for their well-being. ${ }^{15}$ They are free to express their opinion. Their views shall be taken into consideration on matters which concern them in accordance

11 Baruffi, M.C., Il principio dei best interests of the child negli strumenti di cooperazione giudiziaria civile europea, in Di Stasi, A.; Rossi, L.S., (eds.), Lo spazio di libertà, sicurezza e giustizia. A vent'anni dal Consiglio europeo di Tampere, Napoli, 2020, pp. 233-254. In the Croatian Family law cfr. Hrabar, D., Uvod u prava djece, in Hrabar, D. (ed.), Prava djece. Multidisciplinarni pristup, Pravni fakultet Sveučilišta u Zagrebu, Zagreb, 2016, pp. 13-37, 27 et seq.

12 Ex plurimis see Cvejić Jančić, O. (ed.), The Rights of the Child in a Changing World, 25 Years after the UN Convention on the Rights of the Child, Springer International Publishing Switzerland, 2016. With regard to Croatian law in the work, see Hlača, N.; Winkler, S., The Rights of the Child: Croatian National Report, pp. 83-96.

13 Bergamini, E., Human rights of the children in the EU context, in Bergamini, E.; Ragni, C. (eds.), Fundamental Rights and Best Interests of the Child in Transnational Families, Intersentia, Cambridge, Antwerp, Chicago, 2019, pp. 3-20.

14 Korać Graovac, A., Povelja o temeljnim pravima Europske unije i obiteljsko pravo, in Korać Graovac, A.; Majstorović, I., (eds.), Europsko obiteljsko pravo, Narodne novine, Zagreb, 2013, pp. 25-51. Stalford, H., Children and the European Union, Rights, Wealfare and Accountability, Modern studies in European Law, Hart Publishing, Oxford and Portland, Oregon, 2012, p. 42. Petrašević, T., Dijete u pravu Europske unije, in Rešetar, B., (ed.), Dijete i pravo, Pravni fakultet u Osijeku, Osijek, 2009, pp. 273-293.

15 Charter of the Fundamental Rights of the European Union, OJ C 202/389, 7.6.2016. 
with their age and maturity." The second paragraph then states that "in all actions relating to children, whether taken by public authorities or private institutions, the child's best interests must be a primary consideration." Finally, the third paragraph states that "the child shall have the right to maintain on a regular basis a personal relationship and direct contact with both parents, unless this is contrary to his or her interests." All three paragraphs concisely reproduce the content of the Convention on the Rights of the Child, confirming its extraordinary influence on European sources. This is an example of the phenomenon of cross-fertilization, whereby the possible absence of specific precepts concerning children is filled in, while affirming the universal scope of the Convention on the Rights of the Child. ${ }^{16}$

Apart from the Charter, the need for greater protection of children has become firmly established in the collective consciousness and is also enshrined in Article 3 of the Treaty on European Union. ${ }^{17}$ Basically, over the last few decades, legal systems throughout Europe have been influenced by numerous reforms that have swept through all countries like a wave (although not necessarily at the same time). In the wake of the changes and the increased movement of families in the common European area, European legislators have also realized the importance of laying down the rules of the principle to strengthen the legal protection of children. ${ }^{18}$

Nonetheless, the reference to the provisions of international sources capable of protecting the fundamental rights of minors may be insufficient if the interpretation of the rules cited is not combined with Article 8 of the European Convention on Human Rights - ECHR (but also with Article 7 of the Charter) aimed at protecting the fundamental right to private and family life of each person. ${ }^{19}$ The combination of these provisions must then be interpolated with the rules of the

16 Hrabar, D., Prava djece u Europskoj uniji - pravni okvir, in Korać Graovac, A.; Majstorović, I. (eds.), Europsko obiteljsko pravo, Narodne novine, Zagreb, 2013, p. 56.

17 Consolidated versions of the Treaty on European Union and the Treaty on the Functioning of the European Union, OJ C 202/1, 7.6.2016. In the literature see Winkler, S., Obiteljski odnosi, in Mišćenić, E. et al., Europsko privatno pravo, Školska knjiga, Zagreb, 2021, pp. 442-485. For a more specific analysis see Franzina, P., The Place of Human Rights in the Private International Law of the Union in Family Matters, in Bergamini, E.; Ragni, C. (eds.), Fundamental Rights and Best Interests of the Child in Transnational Families, Intersentia, Cambridge, Antwerp, Chicago, 2019, pp. 141-155.

18 Hrabar, op. cit., note 17, p. 53 et seq.; Petrašević, op. cit., note 15, p. 289.

19 Hrabar, D., Posredni utjecaj Vijeća Europe na Europsku uniju u svjetlu obiteljskopravnih vrijednosti, Godišnjak Akademije pravnih znanosti Hrvatske, 10, 2019, 1, pp. 133-162. As to the importance of art. 3 of the Convention on the Rights of the Child see: de Graaf, C., The Legal Impact of Article 3 CRC as a Corrective Remedy - Is Article 3 CRC to Youth Law what Article 8 ECHR was/is to Family Law?, in Rogerson, C. et al. (eds.), Family Law and Family Realities, 16th ISFL World Conference Book, Eleven International Publishing, The Hague, 2019, pp. 421-433. More on human rights in the EU in CrnićGrotić, V.; Sgardelli Car, N., Ljudska prava u Europskoj uniji i praksi Europskog suda u Luksemburgu, Zbornik Pravnog fakulteta u Zagrebu, 60, 2010, 5, pp. 971-994. 
individual national systems. Hence the difficulty and originality of the argumentative paths followed in view of the different cultures, traditions and social contexts that inevitably permeate the family law of each country. ${ }^{20}$

Article 8(1) of the ECHR provides that "everyone has the right to respect for his private and family life, his home and his correspondence." Similarly, moving to the level of primary EU law, Article 7 of the Charter of Fundamental Rights of the EU states that "everyone has the right to respect for his private and family life, his home and his communications." Leaving aside some minor terminological differences, the two rules are practically equivalent, even though they were written almost fifty years apart. Thus, it is undisputed in the doctrine and case-law that the protection of private as well as family life is elevated to the rank of fundamental human rights. Still, neither of these provisions offers a definition of family. This is not surprising since the legal regulation of family relationships is an exclusive competence - at least with regards to substantive law - of each national legislator. Every person's family life - including children's - enjoys authoritative protection and any breach of it is sanctioned in the first instance by the European Court of Human Rights, which ensures that the fundamental rights enshrined in the Convention are respected.

When speaking specifically about the family life of a child, the importance of recalling all the sources mentioned so far becomes clear, especially with regards to the rights of the child in his or her family. Every child has the right to live with his or her parents; in other words, the right to the unity of the family or, if this is not possible, to maintain personal contact with both parents. Even outside the boundaries of the nuclear family, every child needs to cultivate relationships with other family members with whom he or she has an emotional involvement (i.e., siblings, grandparents...). However, it should be pointed out that there is always a limit given by the primacy of the child's best interests. This concept will be discussed below, as will the impact of the pandemic on the various aspects of the child's family life.

After all, the importance of the child's need to have personal contact with his or her family is reconfirmed by the existence of other international conventions issued within the Council of Europe. ${ }^{21}$ These conventions are: the European Convention on the Exercise of Children's Rights, adopted by the Council of Europe in Stras-

\footnotetext{
20 Gephart, W., Family Law as Culture, in Boele-Woelki, K.; Dethloff, N.; Gephart, W. (eds.), Family Law and Culture in Europe, Intersentia, Cambridge - Antwerp - Portland, 2014, pp. 347-360. For an interesting and comprehensive historical reconstruction see Antokolskaia, M., Harmonisation of Family Law in Europe: A Historical Perspective, A Tale of two Millennia, Intersentia, Antwerp - Oxford, 2006.

${ }_{21}$ Majstorović, op. cit., note 10, pp. 47-48.
} 
bourg on 25 January 1996 and Convention on Contact concerning Children, adopted by the Council of Europe in Strasbourg on 15 May 2003..$^{22}$ Although they deal with issues of absolute significance, since now they remain almost ignored because the vast majority of member countries of the Council of Europe have not ratified them.

\section{THE CONCEPT OF THE BEST INTERESTS OF THE CHILD}

There is no doubt that, when deciding in actions concerning children, the impact of Covid-19 on children's rights begs the question what is in the child's best interests in this extraordinary situation. Indeed, we are questioning the real meaning of some concepts that prima facie might at times be taken for granted, such as the best interests of the child. As far as we are concerned, some new questions arise. How are these interests to be assessed when guaranteeing the protection of the rights of the child in times of a pandemic?

Actually, even in the pre-Covid-19 era, i.e., during "normal" life conditions, the interpretation of the concept of the best interests of the child was the subject of numerous evaluations. ${ }^{23}$

Article 3(1) of the Convention in the Right of the Child states "in all actions concerning children, whether taken by public or private social welfare institutions, courts of law, administrative authorities or legislative bodies, the best interests of the child shall be a primary consideration." It follows clearly from the provision that the best interests of the child is paramount in the legal protection of the child in any decision affecting him or her in any way and with reference to any person. The point is that the Convention on the Rights of the Child does not define what it means by 'best interests of the child.' Many years after the Convention was issued, the General Comment No. 14 of the UN Committee on the Rights of the Child finally helps to interpret the best interests of the child. ${ }^{24}$ According to the explanation offered by this source, the notion of the best interests of the child is

22 Hrabar, D., Europska konvencija o ostvarivanju dječjih prava - poseban zastupnik djeteta, in Dijete u pravosudnom postupku - Primjena Europske konvencije o ostvarivanju dječjih prava. Zbornik priopćenja sa stručnih skupova pravobraniteljice za djecu, Zagreb, 2012, pp. 103-116; Lulić, M.; Rešetar, B., Međunarodne obveze Republike Hrvatske vezane uz provedbu Konvencije o kontaktima s djecom (2003), in Rešetar, B. (ed.), Pravna zaštita prava na (zajedničku) roditeljsku skrb, Pravni fakultet u Osijeku, Osijek, 2012., pp. 89-119.

23. An interesting analysis is offered by Long, J., Il principio dei best interests e la tutela dei minori, available at: [https://www.questionegiustizia.it/speciale/articolo/il-principio-dei-best-interests-e-la-tutela-deiminori_86.php], Accessed 25 March 2021.

24 Committee on the Rights of the Child: [https://www2.ohchr.org/English/bodies/crc/docs/GC/ CRC_C_GC_14_ENG.pdf]. 
composed of three aspects. Firstly, the best interests of the child would be understood as a real right of the child to have his or her best interests assessed and taken into substantive consideration $;{ }^{25}$ secondly, it would be an interpretative source; ${ }^{26}$ finally, the best interests of the child would be a procedural rule in any situation where a matter concerning a child is to be decided. ${ }^{27}$

The concept of the best interests of the child is not built on objective characteristics; on the contrary, it necessarily requires a case-by-case assessment. What may be in the best interests of a certain child at a given moment in history and in a given social context is not so true for every child living in the same reality.

This is how the concept is interpreted also in the Croatian family law literature. Namely, on the occasion of the analysis of the transposition of the Convention into Croatian family law in the doctrine, it has been observed that this "new legal concept" cannot be generalized, nor can it be relativized, but must be assessed on a case-by-case basis. More specifically, it has been noticed that, although the concept of the best interests of the child is not defined, it is definable. ${ }^{28}$ In fact, the acknowledgement of the best interests of the child is closely linked to the detection of a specific need of the child that must be met in the best possible way. This specific need of the child must be understood as functional to the optimal psychophysical and emotional development of the child, which is enshrined in the Convention on the Rights of the Child as one of the most important minor's rights. As clearly underlined in the family law literature, for this purpose three elements are relevant: 1) the needs of the child, 2) the autonomy of the parents in the exercise of parental responsibility, and 3) the circumstances, the environment, the conditions, the society - which may be referred to as environmental factors - in which the child lives. ${ }^{29}$ It is quite evident that the latter has quite changed throughout the last year.

In addition, see the very recent General comment No. 25 (2021) on children's rights in relation to the digital environment, of 2 March 2021, available at: [https://tbinternet.ohchr.org/_layouts/15/treatybodyexternal/Download.aspx?symbolno=CRC/C/GC/25\&Lang=en], Accessed 25 March 2021.

25 Quoting Comment no. 14: "Article 3, paragraph 1, (...) gives the child the right to have his or her best interests assessed and taken into account as a primary consideration in all actions or decisions that concern him or her, both in the public and private sphere."

26 Again, Comment no. 14, where it is highlighted how the concept of the best interests of the child is considered even as a "fundamental, interpretative legal principle."

27 Finally, in Comment no. 14, it can be found that this concept represents also a rule of the procedure. Indeed, quoting: "the decision-making process must include an evaluation of the possible impact (positive or negative) of the decision on the child or children concerned."

28 Hrabar, D., Pravni odnosi roditelja i djece, in Alinčić, M. et al., Obiteljsko pravo, Narodne novine, Zagreb, 2007, pp. 126-307, pp. 234 et seq.

29 Hrabar, op. cit., note 29, p. 236. 
Could the Covid-19 emergency (always) be considered as a circumstance justifying the restriction of children's rights since any other decision would be against the best interests of the child?

\section{THE IMPACT OF COVID-19 ON CHILDREN'S RIGHTS}

After the reconstruction of children's fundamental rights, which was purposely carried out on the supranational level, since the question of the impact of the pandemic concerns all minors regardless of the individual national legal systems, it is time to consider how the pandemic has affected these rights. A distinction was previously made between children's rights guaranteed within his or her families and children's rights in relation to the community. In the continuation, situations of severe limitations of children's rights in both segments will be considered.

Regarding children's rights in their own families, in times of Covid-19, the right to live with their parents or to maintain regular contacts with the parent with whom they do not live is seriously compromised. ${ }^{30}$ Thus, seen from the point of view of both children and parents, the right to co-parenting suffers great limitations in times of Covid-19. ${ }^{31}$

The absolute centrality of that right in the life of the child is certainly confirmed by Article 9 of the Convention on the Rights of the Child and Article 24 of the Charter, which must be read in conjunction with Article 7 of the Charter and Article 8 of the ECHR. Regarding national legislation, Article 84(3) of the Croatian Family Act also expressly refers to the right of the child to live with his or her parents. ${ }^{32}$ Moreover, given the universal scope of the Convention on the Rights of the Child, it is not at all surprising that many other jurisdictions also have an equivalent provision affirming the right of the child to live with his or her parents or, where this is not possible, the right to co-parenting by maintaining stable contact with the parent with whom the child does not live permanently. ${ }^{33}$

30 As already mentioned, on the same way it can be noticed a limitation on the minor's right to maintain relations with the other family members i.e., siblings, granparents and other relatives or persons other than relatives with whom the child has emotional ties.

31 From a psychological point of view see Roskam, I., Psychological Insights. Parent-Child Relationships in the Light of Psychology, in Sosson, J.; Willems, G.; Motte, G. (eds.), Adults and Children in Postmodern Societies, A Comparative Law and Multidisciplinary Handbook, Intersentia, Cambridge - Antwerp Chicago, 2019, p. 669.

32 Croatian Family Act (Obiteljski zakon), Official Gazzette No. 103/2015, 98/19 and 47/20. In the literature see Hrabar, D., Prava djece u obiteljskom zakonodavstvu, in Hrabar, D. (ed.), Prava djece. Multidisciplinarni pristup, Pravni fakultet Sveučilišta u Zagrebu, Zagreb, 2016, p. 69.

33 Among many see art. 315-bis of the Italian Civil code (codice civile) and $\$ 1626$ of the German Civil code (BGB Bürgerliches Gesetzbuch). 
As already mentioned, this right is, in any case, subject to the assessment of the best interests of the child. Therefore, is the risk of infection by Covid-19 always an element justifying the limitation of the exercise referred to above? Can the right to co-parenting be contrary to the best interests of the child because of Covid-19? Of course, the answer can never be unequivocal. In some cases, the limitation will be justified; in others, however, it might not be.

Unfortunately, the health emergency we are experiencing also lends itself to easy manipulative tactics aimed at undermining the relationship between the child and one of the parents. In the context of the many problems that exist, especially when there are situations of conflict between ex-parents or ex-partners, it is legitimate to ask whether this extraordinary situation is being abused, leading to the child being voluntarily removed from the non-custodial parent.

This is about conducts that are not aimed at protecting health, but at exacerbating family conflicts, or even worse, behaviours through which the children are exploited to advance the opposing and conflicting positions of the two parents. Actions which, in the end, violate the right to family life. But one cannot look at it only in a pessimistic way. It has to be said that there are parents who, on the other hand, renounce visiting rights in order not to expose their children to health risks. We could call it a "renouncement of love."

Thinking hypothetically about the practical resolution of these problems, although it is too early to discuss case-law as we are still living in an emergency, some decisions can be found in national experiences, especially when discussing urgent measures. While it is difficult to find precedents in our legal system during a pandemic, some decisions can be found above all in the jurisprudence of the most populous states in Europe, which have also been subjected to very restrictive anti-covid-19 measures in recent months. One such example is Italy, where in the very present moment, we may observe a significant compression of the child's right to maintain regular relations and direct contacts with the parent with whom he or she does not live permanently. ${ }^{34}$

In reality, this compression is evident even where, as the courts often rightly argue, there is no basis for it: a health emergency in itself should not legitimize the suspension of contact with the non-custodial parent unless there are specific health risks. In that case, there are alternative ways (video platforms, video calls, telematic tools) capable of preserving the affective relationship between the child and the

34 Silvestri, C., Chiaroscuri della frequentazione genitori-figli nell'emergenza coronavirus, approfondimento 24 aprile 2020, Giustizia civile.com, pp. 2-15. 
parent, albeit by transposing it into virtual reality - even on a daily basis. ${ }^{35}$ Concretely, alternative ways of maintaining the relationship are possible and needed. The aim is not so much (or only) to guarantee the relationship in the present, but to try to preserve it in the future, in the post-Covid life. It is known that not being in touch risks souring the relationship as well as that distance might lead to dissolvement of relationships and affections. These problems are even more difficult to solve in the presence of cross-border elements. ${ }^{36}$

In all these situations, the importance of guaranteeing the child the right to be heard emerges fully; but even before being heard, the child has the right to be informed. Indeed, recalling once again the UN Convention on the Rights of the Child, as well as the Charter of EU fundamental Rights or the European Convention on the Exercise of Children's Rights, all these sources enshrine the right of the child to express his or her opinion and to be informed of the facts concerning any action that may affect their lives. Of course, children's right to be informed and heard has to be practised in a manner appropriate to their age and maturity. It goes without saying that, in times of a pandemic, children should be informed about the health emergency and the consequences of the spread of the Covid-19 infection.

The protection of the exercise of children's rights, as listed above, depends on this. Every child has the right to be enabled to understand the context in which he or she lives in order to be able to consciously express his or her opinion. Even more so now that many of their rights are being curtailed, children have the right to know what is happening in the world around them.

In the second large group, we include the rights that children have in the context of the society in which they live, or rather the community to which they belong.

However, before moving on to some reflections on these rights, we need to reflect further on one aspect of the child's life within his or her family. The family environment, which until now has been spoken of as the natural society that in a pandemic should be the safe refuge for every person, a warm home that offers pro-

35 Piazzoni, D., Diritto alla bigenitorialità, diritto di visita e frequentazione e coronavirus: un mosaico in composizione?, approfondimento del 04 maggio 2020, Giustizia civile.com, pp. 2-22.

36 In general, with regards to issues concerning children in cross-border situations, many insights can be found in Kunda, I. (ed.), Obitelj i djeca: Europska očekivanja i nacionalna stvarnost/Family and children: European expectations and national reality, Pravni fakultet u Rijeci, Hrvastka udruga za poredbeno pravo, Rijeka, 2014, as well as in Župan, M., Dijete u međunarodnom privatnom pravu, in Rešetar, B. (ed.), Dijete i pravo, Osijek, 2009, pp. 223-257. In addition, it is useful to take note of the HCCH COVID-19 Toolkit available at: [https://www.hcch.net/en/news-archive/details/?varevent=731], Accessed 20 March 2021. 
tection especially to the most vulnerable, has unfortunately turned into a prison for many. Indeed, in times of Covid-19, the domestic walls have seen far too much domestic violence. ${ }^{37}$ Thus, another very serious problem has been identified in recent months as the difficulty to protect children from domestic violence. The pandemic has paralyzed a large part of the justice system and so, in the isolation that kept us in our homes, many child victims of domestic violence have been literally imprisoned at home with violent parents and/or family members. ${ }^{38}$ Actually, only in the future will it be possible to understand the true extent of the violence that is now taking place in lockdowns, which will affect children's psychophysical and emotional development.

Without wishing to diminish the seriousness of the violence that is taking place in many families and harming many children, it must be noted that this pandemic will also cause many worrying economic consequences, which will undermine the stability of many families. ${ }^{39} \mathrm{I}$ am referring here both to the right to maintenance and, more generally, to poverty. ${ }^{40}$ How will these affect family life? What impact will this have on the relationship between parents and children?

Poverty is, unfortunately, like a bridge that brings into the social context the manifestation of the reality that the child lives in his or her family. In times of Covid-19, poverty has an even greater impact on social exclusion, undermining the rights, even the fundamental rights, of children - especially the most unfortunate ones who live on the margins of society. ${ }^{41}$

37 Several studies have been carried out this issue. More details are available at: [http://www.emro.who. int/violence-injuries-disabilities/violence-news/levels-of-domestic-violence-increase-as-covid-19-pandemic-escalates.html]. See also: [https://eige.europa.eu/publications/covid-19-pandemic-and-intimate-partner-violence-against-women-eu], Accessed 25 March 2021. Since the beginning of the pandemic in 2020, there has been a need to study the impact of Covid-19 on domestic violence by conducting research in the psychiatric field. See Roje Đapić, M.; Buljan Flander, G.; Prijatelj, K., Children Behind Closed Doors Due to COVID-19 Isolation: Abuse, Neglect and Domestic Violence, Archives of Psychiatry Research, 56, 2020, pp. 181-192.

38 Rittossa, D.; Golenko, D., Information Needs of Vulnerable Groups in the Time of COVID-19: The Theoretical Framework, in Sander, G. G.; Pošćić, A.; Martinović, A. (eds.), Exploring the Social Dimension of Europe, Essays in honour of prof. Nada Bodiroga Vukobrat, Verlag Dr. Kovač, Hamburg, 2021, pp. 407-419.

39 Poverty was a very worrying problem long before the pandemic. For more see Combating child poverty: an issue of fundamental rights, dating from 2018 and available at: [https://fra.europa.eu/en/publication/2018/combating-child-poverty-issue-fundamental-rights], Accessed 23 March 2021.

40 With regards to the relationship between poverty and rights see Rodotà, S., Il diritto di avere diritti, Editori Laterza, Bari, 2012, pp. 232-242.

41 About the child's poverty and the impact of Covid-19 see: [https://data.unicef.org/topic/child-poverty/overview/], see also [https://www.unicef.org/social-policy/child-poverty]. Accessed 23 March 2021. In the doctrine, see Hlača, N., Ljudska prava u siromasttvu, Godišnjak Akademije pravnih znanosti Hrvatske, vol. X, 1/2019, pp. 119-131. Speaking about children's poverty see Družić Ljubotina, O.; 
The "new poverty" is characterized by indebtedness and economic uncertainty, unemployment, job loss, falling incomes, rising education costs, as well as by the increase of the number of citizens living in absolute poverty (homelessness - including children). ${ }^{42}$

The unequal treatment of children during the pandemic because of the different economic families' capacities clearly emerges when it comes to the exercise of a fundamental right such as the right to education. ${ }^{43}$ During these months, distance learning is being practiced almost everywhere depending on the waves and peaks of the Covid-19 infection. Do all children have the same chances and conditions to educate themselves in these extraordinary living conditions? Even before that, did they all have access to the internet? Do they have the same computer equipment? Clearly, the answer is no.

In the very present moment, the existence of a digital divide is unavoidable. Indeed, the various economic possibilities of the families will lead to a disparity in the use of educational services through technological tools, which risks creating discrimination among minors. The possible violation of the right to education combined with the danger of an evident discrimination against children represents a real risk.

A number of issues arise in this respect that should be highlighted here. The first question is related to the digital world itself and has a wider scope than just the protection of children's rights: is the right to access the internet to be understood as a fundamental right? There is a debate on this point and, in connection with this, there is also the question whether the impossibility of accessing the internet actually entails a form of social exclusion. In particular, this refers to the already mentioned phenomenon of the digital divide, which can lead to a form of social segregation and de facto could be described as an expression of the so-called new poverty. Thinking about the education in the pandemic life, it would be nice to

Kletečki Radović., M., Siromaštvo i djeca, in Hrabar, D. (ed.), Prava djece. Multidisciplinarni pristup, Pravni fakultet Sveučilišta u Zagrebu, Zagreb, 2016, pp. 243-281, pp. 256 et seq.

42 When it comes to „absolute poverty” the right to food comes into question. In particular about this right during the Covid-19 pandemic see Vinković, M., Hunger as a Social Problem - the Right to Food in a Time of Crisis, in Sander, G.G.; Pošćić, A.; Martinović, A., Exploring the Social Dimension of Europe, Essays in Honour of Nada Bodiroga-Vukobrat, Verlag dr. Kovač, Hamburg, 2021, pp. 87-97, pp. 91 et seq.

43 See The European Child Guarantee: [https:/ec.europa.eu/info/policies/justice-and-fundamental-rights/rights-child/eu-strategy-rights-child-and-european-child-guarantee_en]. The goal of this document is to support persons under the age of 18 at risk of poverty or social exclusion. See also: [https://ec.europa.eu/info/strategy/priorities-2019-2024/economy-works-people/jobs-growth-andinvestment/european-pillar-social-rights/european-pillar-social-rights-action-plan/skills-and-equality_en], Accessed 20 April 2021. 
imagine all children having the same possibilities and that the emergency has in fact "only" forced a shift from the old normal offline to the new normal online. Unfortunately, access to and use of the new technologies, which should serve as a suitable tool for adapting to the new forms of exercising fundamental rights, such as the fundamental right to education, appears to be a right in itself, or rather, a privilege that cannot be enjoyed by all children. It is rightly considered that IT inclusion should be a fundamental right of individuals, otherwise, the different economic capacities of families would lead to a disparity in the use of educational services through technological tools, which risks creating discrimination among minors and isolation from online relationships, which, in conclusion, generates a digital divide. This would basically lead to discriminatory consequences and, thus, to a possible violation of Article 14 of the ECHR. Reflecting on the digital divide, it must be stressed that it is not limited to the impossibility of connecting to the network. Instead, it goes deeper and refers to the consequent impossibility of acquiring information and knowledge necessary to be able to become part of the digital world. The fundamental problem lies in the fact that the digital divide creates profound differences in the level of information acquired depending on whether or not a child has the possibility of accessing the internet and, more generally, whether or not he or she has the computer tools necessary to achieve this goal. A recent report published by UNICEF offers very discouraging data: more than two-thirds of the world's school-age children do not have access to the internet. ${ }^{44}$

This gap can have various consequences, many of which, recalling another fundamental right of the child, can have a negative impact on his or her psychophysical and emotional development, as well as on his or her right to be informed. In fact, this gap leads to different levels of digital skills from subject to subject, which inevitably reflect in the different forms of expression of the person and involve different developments of cognitive faculties. ${ }^{45}$ Moreover, it should be of very serious concern that the digital divide hinders the subject (child) in the conscious and responsible use of the network. ${ }^{46}$

44 For more see [https://www.unicef.org/press-releases/two-thirds-worlds-school-age-children-have-nointernet-access-home-new-unicef-itu], Accessed 23 March 2021.

45 For more see the General comment No. 25 (2021) on children's rights in relation to the digital environment. Specifically, the document stresses the importance of the child's "evolving capacities."

46 Lisičar, H., Pravni aspekti zaštite maloljetnika u elektroničnim medijima, in Hrabar, D. (ed.), Prava djece. Multidisciplinarni pristup, Pravni fakultet Sveučilišta u Zagrebu, Zagreb, 2016, pp. 119-145. Generally speaking about the right to education in the context of the Charter of fundamental rights of the EU see Korać Graovac, op. cit., note 15, p. 42. Stalford, op. cit., note 15, p. 143 et seq. 
In addition to the right to education, another right that is seriously compromised is the right to play. Namely, Article 31 of the Convention on the Rights of the Child enshrines a specific right for all children to have rest and leisure, to engage in play and recreational activities proper to their age, and to join freely in cultural life and the arts.

Among these, rights such as access to education, recreation, and a balanced psychophysical development of the child are being severely tested at the present time.

From a psychological point of view, distance learning as well as the limitation of opportunities for play and leisure lead to the conclusion that the impact of Covid-19 is devastating on the psychophysical and emotional development of children. The absence of the socialization normally associated with school and leisure activities carries a serious risk of damaging the health (especially mental health) of children.

\section{WHAT IS THE FUTURE OF CHILDREN'S RIGHTS IN THE POST-COVID WORLD? SOME CONCLUDING REMARKS}

After having made a "snapshot" of the current state of children's rights, we need to ask ourselves what will happen once we return to normal life, or at least once the state of emergency is over.

As far as the rights of minors within the family are concerned, it seems necessary to continue strengthening legislative policies aimed at providing minors with concrete protection of their rights. It means to strengthen children's right to be informed in all situations that concern him or her, as well as his or her right to be heard. Hopefully the post-Covid-19 period will serve to awaken the adults about the need to listen to children: the exercise of such a right allows an informed assessment of what is really in the best interests of the child. ${ }^{47}$ Referring to the policies of the "child friendly justice," although these goals are already present as fixed point on the national and supranational agendas with regard to the protection of children's rights, such rules should become binding. ${ }^{48}$

47 In this regard, see Korać Graovac, A., Pravo djeteta da bude saslušano - Opći komentar br. 12 Odbora $z a$ prava djeteta (2009.), in Dijete u pravosudnom postupku - Primjena Europske konvencije o ostvarivanju dječjih prava. Zbornik priopćenja sa stručnih skupova pravobraniteljice za djecu, Zagreb, 2012, pp. 117-137. Majstorović, I., The realisation of the right of the child to express his/her views - How "visible" are children in Croatian family judicial proceedings?, Ljetopis socijalnog rada, 24, 2017, 1, pp. 55-71.

48 Regarding child-friendly justice see the Guidelines of the Committee of Ministers of the Council of Europe on child friendly justice available at: [https://www.coe.int/en/web/children/child-friendly-justice], see also: [https://fra.europa.eu/sites/default/files/fra-2015-child-friendly-justice-professionals_en.pdf], 
As far as the rights of the child in the social context are concerned, this pandemic has shown the many vulnerabilities of society in caring for children. One among them appears to be of worrying proportions: the digital divide.

Nowadays, it is unimaginable that a person - especially a child - is unable to exercise his or her rights (not only those to education) in the same way offline and online. A genuine digital revolution should lead to the realization of this purpose.

Equal opportunities, which also include combating the new forms of energy poverty, must be guaranteed to all minors so as not to create discrimination and different opportunities for growth and psychophysical development. ${ }^{49}$

A first step that at least shows an awareness of the gravity of the situation seems to have been taken at the supranational level with the issuing of The EU Strategy on the Rights of the Child and the European Child Guarantee on 24 March 2021. ${ }^{50}$ It is now hoped that the efforts made in times of the pandemic to protect children, who are certainly among the most traumatized by this situation, will not come to a standstill once the acute phase of the emergency has been overcome. The various efforts made at the international and supranational level must contribute to a systematic improvement in national legislative policies aimed at improving the protection of children's rights.

"All grown-ups were once children... but only few of them remember it." Antoine de Saint-Exupéry, The Little Prince

\section{REFERENCES}

\section{BOOKS AND ARTICLES}

1. Antokolskaia, M., Harmonisation of Family Law in Europe: A Historical Perspective, A Tale of two Millennia, Intersentia, Antwerp - Oxford, 2006

Accessed 23 March 2021. Cf. Carpaneto, L., Impact of the Best Interests of the Child on the Brussels II ter Regulation, in Bergamini, E.; Ragni, C. (eds.), Fundamental Rights and Best Interests of the Child in Transnational Families, Intersentia, Cambridge, Antwerp, Chicago, 2019, pp. 265-285.

49 See supra footnotes 40, 41, and 42 and the European Parliament resolution of 14 April 2016 on meeting the antipoverty target in the light of increasing household costs (2015/2223(INI)), OJ C 58/192, 15.2.2018.

50 The EU Strategy on the Rights of the Child and the European Child Guarantee are available at: [https://ec.europa.eu/info/policies/justice-and-fundamental-rights/rights-child/eu-strategy-rights-child-and-european-child-guarantee_en]. See also: [https://ec.europa.eu/info/sites/default/ files/child_rights_strategy_version_with_visuals3.pdf], Accessed 15 April 2021. 
2. Baruff, M.C., Il principio dei best interests of the child negli strumenti di cooperazione giudiziaria civile europea, in Di Stasi, A.; Rossi, L.S. (eds.), Lo spazio di libertà, sicurezza e giustizia. A vent'anni dal Consiglio europeo di Tampere, Napoli, 2020, pp. 233-254

3. Bergamini, E., Human rights of the children in the EU context, in Bergamini, E.; Ragni, C. (eds.), Fundamental Rights and Best Interests of the Child in Transnational Families, Intersentia, Cambridge, Antwerp, Chicago, 2019, pp. 3-20

4. Carpaneto, L., Impact of the Best Interests of the Child on the Brussels II ter Regulation, in Bergamini, E.; Ragni, C. (eds.), Fundamental Rights and Best Interests of the Child in Transnational Families, Intersentia, Cambridge, Antwerp, Chicago, 2019, pp. 265-285

5. Crnić-Grotić, V.; Sgardelli Car, N., Ljudska prava u Europskoj uniji i praksi Europskog suda u Luksemburgu, Zbornik Pravnog fakulteta u Zagrebu, 60, 2010, 5, pp. 971-994

6. Cuocolo, L. (ed.), I diritti costituzionali di fronte all'emergenza Covid-19. Una prospettiva comparata, Osservatorio emergenza covid-19, 18.3.2020., Federalismi.it, pp. 3-96

7. Cvejić Jančić, O. (ed.), The Rights of the Child in a Changing World, 25 Years after the UN Convention on the Rights of the Child, Springer International Publishing Switzerland, 2016

8. de Graaf, C., The Legal Impact of Article 3 CRC as a Corrective Remedy - Is Article 3 CRC to Youth Law what Article 8 ECHR was/is to Family Law?, in Rogerson, C. et al. (eds.), Family Law and Family Realities, 16th ISFL World Conference Book, Eleven International Publishing, The Hague, 2019, pp. 421-433

9. Dolso, G. P., Ferrara, M. D., Rossi, D. (eds.), Virus in fabula, Diritti e Istituzioni ai tempi del covid-19, EUT Edizioni Università di Trieste, 2020. [https://www.openstarts.units.it/ handle/10077/30878], Accessed 1 March 2021

10. Dolso, G. P., Emergenza sanitaria e libertà di circolazione, in Dolso, G. P.; Ferrara, M. D.; Rossi, D. (eds.), Virus in fabula, Diritti e Istituzioni ai tempi del covid-19, EUT Edizioni Università di Trieste, 2020, pp. 263-278

11. Družić Ljubotina, O.; Kletečki Radović., M., Siromaštvo i djeca, in Hrabar, D. (ed.), Prava djece. Multidisciplinarni pristup, Pravni fakultet Sveučilišta u Zagrebu, Zagreb, 2016, pp. 243-281

12. Fiorentini, M., Caelum pestilens. Riflessi delle pandemie antiche nel diritto romano, in Dolso, G. P.; Ferrara, M. D.; Rossi, D. (eds.), Virus in fabula, Diritti e Istituzioni ai tempi del covid-19, EUT Edizioni Università di Trieste, 2020. [https://www.openstarts.units.it/ handle/10077/30878], pp. 47-60, Accessed 1 March 2021

13. Franzina, P., The Place of Human Rights in the Private International Law of the Union in Family Matters, in Bergamini, E.; Ragni, C. (eds.), Fundamental Rights and Best Interests of the Child in Transnational Families, Intersentia, Cambridge, Antwerp, Chicago, 2019, pp. 141-155

14. Gephart, W., Family Law as Culture, in Boele-Woelki, K.; Dethloff, N.; Gephart, W. (eds.), Family Law and Culture in Europe, Intersentia, Cambridge - Antwerp - Portland, 2014, pp. 347-360

15. Gioffredi, G., La pandemia Covid-19 e la tutela dei diritti umani nel sistema delle Nazioni Unite, in Ellerani, P.; Cristante, S. (eds.), Le Scienze Umane alla prova della distanza sociale, Liber-O. Collana Didattica Open Access dell’Università del Salento, 2020, pp. 61-74 
16. Hlača, N., Ljudska prava u siromaštvu, Godišnjak Akademije pravnih znanosti Hrvatske, vol. $\mathrm{X}, 1 / 2019$, pp. 119-131

17. Hlača, N.; Winkler, S., The Rights of the Child: Croatian National Report, in Cvejić Jančić, O. (ed.), The Rights of the Child in a Changing World, 25 Years after the UN Convention on the Rights of the Child, Springer International Publishing Switzerland, 2016, pp. 83-96

18. Hrabar, D., Posredni utjecaj Vijeća Europe na Europsku uniju u svjetlu obiteljskopravnih vrijednosti, Godišnjak Akademije pravnih znanosti Hrvatske, 10, 2019, 1, pp. 133-162

19. Hrabar, D. (ed.), Prava djece. Multidisciplinarni pristup, Pravni fakultet Sveučilišta u Zagrebu, Zagreb, 2016

20. Hrabar, D., Uvod u prava djece, in Hrabar, D. (ed.), Prava djece. Multidisciplinarni pristup, Pravni fakultet Sveučilišta u Zagrebu, Zagreb, 2016, pp. 13-37

21. Hrabar, D., Prava djece u obiteljskom zakonodavstvu, in Hrabar, D. (ed.), Prava djece. Multidisciplinarni pristup, Pravni fakultet Sveučilišta u Zagrebu, Zagreb, 2016, pp. 63-81

22. Hrabar, D., Prava djece u Europskoj uniji-pravni okvir, in Korać Graovac, A.; Majstorović, I. (eds.), Europsko obiteljsko pravo, Narodne novine, Zagreb, 2013, pp. 53-71

23. Hrabar, D., Europska konvencija o ostvarivanju dječjih prava-poseban zastupnik djeteta, in Dijete u pravosudnom postupku - Primjena Europske konvencije o ostvarivanju dječjih prava. Zbornik priopćenja sa stručnih skupova pravobraniteljice za djecu, Zagreb, 2012, pp. 103116

24. Hrabar, D., Pravni odnosi roditelja i djece, in Alinčić, M. et al., Obiteljsko pravo, Narodne novine, Zagreb, 2007, pp. 125-307

25. Hrabar, D., Dijete - Pravni subjekt u obitelji, Zagreb, 1994

26. Korać Graovac, A., Povelja o temeljnim pravima Europske unije i obiteljsko pravo, in Korać Graovac, A.; Majstorović, I., (eds.), Europsko obiteljsko pravo, Narodne novine, Zagreb, 2013, pp. 25-51

27. Korać Graovac, A., Pravo djeteta da bude saslušano - Opći komentar br. 12 Odbora za prava djeteta (2009.), in Dijete u pravosudnom postupku - Primjena Europske konvencije o ostvarivanju dječjih prava. Zbornik priopćenja sa stručnih skupova pravobraniteljice za djecu, Zagreb, 2012, pp. 117-137

28. Kunda, I. (ed.), Obitelj i djeca: Europska očekivanja i nacionalna stvarnost/Family and children: European expectations and national reality, Pravni fakultet u Rijeci, Hrvastka udruga za poredbeno pravo, Rijeka, 2014

29. Lisičar, H., Pravni aspekti zaštite maloljetnika u elektroničnim medijima, in Hrabar, D. (ed.), Prava djece. Multidisciplinarni pristup, Pravni fakultet Sveučilišta u Zagrebu, Zagreb, 2016, pp. 119-145

30. Long, J., Il principio dei best interests e la tutela dei minori [https://www.questionegiustizia. it/speciale/articolo/il-principio-dei-best-interests-e-la-tutela-dei-minori_86.php], Accessed 25 March 2021

31. Lulić, M.; Rešetar, B., Medunarodne obveze Republike Hrvatske vezane uz provedbu Konvencije o kontaktima s djecom (2003), in Rešetar, B. (ed.), Pravna zaštita prava na (zajedničku) roditeljsku skrb, Pravni fakultet u Osijeku, Osijek, 2012., pp. 89-119 
32. Majstorović, I., The realisation of the right of the child to express his/her views - How "visible" are children in Croatian family judicial proceedings?, Ljetopis Socijalnog Rada, 24, 2017, 1, pp. 55-71

33. Majstorović, I., Europski obiteljskopravni sustav zaštite djece, in Hrabar, D. (ed.), Prava djece. Multidisciplinarni pristup, Pravni fakultet Sveučilišta u Zagrebu, Zagreb, 2016, pp. 39-62

34. Petrašević, T., Dijete u pravu Europske unije, in Rešetar, B., (ed.), Dijete i pravo, Pravni fakultet u Osijeku, Osijek, 2009, pp. 273-293

35. Piazzoni, D., Diritto alla bigenitorialità, diritto di visita e frequentazione e coronavirus: un mosaico in composizione?, approfondimento del 04 maggio 2020, Giustizia civile.com, pp. 2-22

36. Pistor, K., Law in the Time of COVID-19, 2020, [https://scholarship.law.columbia.edu/ books/240], Accessed 1 March 2021

37. Rešetar, B. (ed.), Dijete i pravo, Pravni fakultet u Osijeku, Osijek, 2009

38. Rittossa, D.; Golenko, D., Information Needs of Vulnerable Groups in the Time of COVID-19: The Theoretical Framework, in Sander, G. G.; Pošćić, A.; Martinović, A. (eds.), Exploring the Social Dimension of Europe, Essays in honour of prof. Nada Bodiroga Vukobrat, Verlag Dr. Kovač, Hamburg, 2021, pp. 407-419

39. Rodotà, S., Il diritto di avere diritti, Editori Laterza, Bari, 2012, pp. 232-242

40. Roje Đapić, M.; Buljan Flander, G.; Prijatelj, K., Children Behind Closed Doors Due to COVID-19 Isolation: Abuse, Neglect and Domestic Violence, Archives of Psychiatry Research, 56, 2020, pp. 181-192

41. Roskam, I., Psychological Insights. Parent-Child Relationships in the Light of Psychology, in Sosson, J.; Willems, G.; Motte, G. (eds.), Adults and Children in Postmodern Societies, A Comparative Law and Multidisciplinary Handbook, Intersentia, Cambridge - Antwerp Chicago, 2019, pp. 657-672

42. Stalford, H., Children and the European Union, Rights, Wealfare and Accountability, Modern studies in European Law, Hart Publishing, Oxford and Portland, Oregon, 2012

43. Vinković, M., Hunger as a Social Problem - the Right to Food in a Time of Crisis, in Sander, G.G.; Pošćić, A.; Martinović, A. (eds.), Exploring the Social Dimension of Europe, Essays in Honour of Nada Bodiroga-Vukobrat, Verlag dr. Kovač, Hamburg, 2021, pp. 87-97

44. Winkler, S., Obiteljski odnosi, in Mišćenić, E. et al., Europsko privatno pravo, Školska knjiga, Zagreb, 2021, pp. 442-485

45. Župan, M., Dijete u međunarodnom privatnom pravu, in Rešetar, B. (ed.), Dijete i pravo, Osijek, 2009, pp. 223-257

\section{EU LAW}

1. Charter of the Fundamental Rights of the European Union, OJ C 202/389, 7.6.2016.

2. Consolidated versions of the Treaty on European Union and the Treaty on the Functioning of the European Union, OJ C 202/1, 7.6.2016.

3. European Parliament resolution of 14 April 2016 on meeting the antipoverty target in the light of increasing household costs (2015/2223(INI)), OJ C 58/192, 15.2.2018. 
4. European Child Guarantee, [https:/ec.europa.eu/info/policies/justice-and-fundamentalrights/rights-child/eu-strategy-rights-child-and-european-child-guarantee_en.], Accessed 15 April 2021

5. [https://ec.europa.eu/info/strategy/priorities-2019-2024/economy-works-people/jobsgrowth-and-investment/european-pillar-social-rights/european-pillar-social-rights-actionplan/skills-and-equality_en], Accessed 20 April 2021

6. EU Strategy on the Rights of the Child and the European Child Guarantee [https:// ec.europa.eu/info/policies/justice-and-fundamental-rights/rights-child/eu-strategy-rightschild-and-european-child-guarantee_en.], Accessed 15 April 2021

7. [https://ec.europa.eu/info/sites/default/files/child_rights_strategy_version_with_visuals3. pdf], Accessed 15 April 2021

\section{LIST OF NATIONAL REGULATIONS, ANCT AND COURT DECISIONS}

1. Croatian Family Act (Obiteljski zakon), Official Gazzette No. 103/2015, 98/19, 47/20

\section{WEBSITE REFERENCES}

1. [http://www.emro.who.int/violence-injuries-disabilities/violence-news/levels-of-domesticviolence-increase-as-covid-19-pandemic-escalates.html], Accessed 1 March 2021

2. [https://data.unicef.org/topic/child-poverty/overview/], Accessed 23 March 2021

3. [https://eige.europa.eu/publications/covid-19-pandemic-and-intimate-partner-violenceagainst-women-eu.], Accessed 20 March 2021

4. [https://fra.europa.eu/sites/default/files/fra-2015-child-friendly-justice-professionals_ en.pdf], Accessed 23 March 2021

5. [https://www.unicef.org/press-releases/two-thirds-worlds-school-age-children-have-no-internet-access-home-new-unicef-itu], Accessed 23 March 2021

6. [https://www.unicef.org/social-policy/child-poverty], Accessed 25 March 2021

7. [https://www2.ohchr.org/English/bodies/crc/docs/GC/CRC_C_GC_14_ENG.pdf], Accessed 23 March 2021

8. Child-friendly justice - Guidelines of the Committee of Ministers of the Council of Europe on child friendly justice, [https:/www.coe.int/en/web/children/child-friendly-justice], Accessed 23 March 2021

9. Combating child poverty: an issue of fundamental rights, [https://fra.europa.eu/en/publication/2018/combating-child-poverty-issue-fundamental-rights] Accessed 23 March 2021

10. Committee on the Rights of the Child [https://www.ohchr.org/EN/HRBodies/CRC/Pages/ CRCIntro.aspx], Accessed 23.03.2021

11. Covid-19 news and resources [https://www.unicef.org/coronavirus/covid-19], Accessed 23 March 2021

12. Croatian Ombudsperson for Children [http://dijete.hr/category/koronavirus/], Accessed 23 March 2021 
13. European Network of Ombudspersons for Children (ENOC), Report on Ombudspersons and Commissioners for Children's Challenges and Responses to COVID-19 [http://enoc. eu/?p=3515], Accessed 23 March 2021

14. General comment No. 25 (2021) on children's rights in relation to the digital environment, of 2 March 2021, [https://tbinternet.ohchr.org/_layouts/15/treatybodyexternal/Download. aspx?symbolno=CRC/C/GC/25\&Lang=en], Accessed 23 March 2021

15. HCCHCOVID-19Toolkit, [https://www.hcch.net/en/news-archive/details/?varevent=731], Accessed 20 March 2021 